\title{
Predicting zooplankton response to environmental changes in a temperate estuarine ecosystem
}

\author{
Sónia Cotrim Marques · Ulisses Miranda Azeiteiro · Sérgio Miguel Leandro · \\ Henrique Queiroga · Ana Lígia Primo · Filipe Martinho · \\ Ivan Viegas $\cdot$ Miguel Ângelo Pardal
}

Received: 31 January 2008/Accepted: 21 August 2008/Published online: 10 September 2008

(C) Springer-Verlag 2008

\begin{abstract}
A novel strategy that allows to predict the responses of zooplanktonic species to environmental conditions in an estuarine temperate ecosystem (Mondego estuary) is presented. It uses 12 indicator species from the zooplanktonic Mondego database (102 species) that are common members of the different habitats, characterized by their specific hydrological conditions. Indicator-species analysis (ISA) was used to define and describe which species were typical of each of the five sampling stations in a 4-year study (2003-2006). First, a canonical correspondence analysis (CCA) was carried out to objectively identify the species-habitat affinity based on the relationship between species, stations and environmental data. Response curves for each of the zooplanktonic species, generated by univariate logistic regression on each of the independent variables temperature and salinity, were generally in agreement with the descriptive statistics concerning the occurrence of those species in this particular estuarine ecosystem. Species-specific models that predict probability of occurrence relative to environmental
\end{abstract}

Communicated by S.A. Poulet.

S. C. Marques $(\bowtie)$ U. M. Azeiteiro · A. L. Primo

F. Martinho $\cdot$ I. Viegas · M. Â. Pardal

Department of Zoology, Institute of Marine Research, IMAR,

University of Coimbra, 3004-517 Coimbra, Portugal

e-mail: scotrim@ci.uc.pt

S. M. Leandro · H. Queiroga

CESAM and Department of Biology, University of Aveiro,

Campus Unversitário de Santiago, 3810-193 Aveiro, Portugal

\section{S. M. Leandro}

Instituto Politécnico de Leiria, Escola Superior de Tecnologia do Mar, Campus 4, Santuário Nossa Senhora dos Remédios, Apartado 126, 2524-909 Peniche, Portugal parameters like salinity, water temperature, turbidity, chlorophyll a, total suspended solids and dissolved oxygen were then developed for the zooplanktonic species. The multiple logistic models used contained between 1 and 3 significant parameters and the percentage correctly predicted was moderate to high, ranging from 62 to $95 \%$. The predictive accuracy of the model was assured by direct comparison of model predictions with the observed occurrence of species obtained in 2006 (validation) and from data collected in the early 2000s in another Portuguese estuary-Ria de Aveiro (Canal de Mira), a complex mesotidal shallow coastal lagoon. The regression logistic model here defined, correctly suggested that the distribution of zooplankton species was mainly dependent on salinity and water temperature. The logistic regression proved to be a useful approach for predicting the occurrence of species under varying environmental conditions at a local scale. Therefore, this model can be considered of reasonable application (and should be tested in other estuarine systems) due to its ability to predict the occurrence of individual zooplanktonic species associated with habitat changes.

\section{Introduction}

Assemblages of species in ecological communities reflect interactions between organisms and the abiotic environment as well as among organisms (Hughes 2000). It is widely accepted that estuarine ecosystems are environmentally unstable, in opposition to freshwater and marine ecosystems (McLusky and Elliott 2004). Zooplankton species are valuable indicators of environmental conditions (Beaugrand 2004; Bonnet and Frid 2004) since they 
respond directly and sensitively to many physical, chemical and biological changes that occur in these ecosystems. Consequently, predicting zooplanktonic community responses to various hydrological forcing and their effects on the estuarine ecosystems constitutes a major challenge on estuarine ecosystems management. Of the multiple physical and chemical factors that influence zooplankton distribution, salinity and temperature are two of the most studied factors. Indeed, many studies have shown that salinity affects the overall composition of the zooplanktonic community, individual species at different stages of their life cycle (e.g. Anger 2003; Queiroga and Blanton 2004) and this is a major determining factor in the distribution of zooplanktonic species in estuaries (e.g. Gaudy et al. 2000; Berasategui et al. 2006; Blanco-Bercial et al. 2006). A number of studies have determined that temperature is also an important environmental factor, strongly affecting vital physiological rates such as respiration (Roddie et al. 1984) and excretion (Gaudy et al. 2000). Temperature and food conditions can also modify the lifehistory traits of zooplanktonic organisms such as copepods, through its influence on egg production (e.g. HalsbandLenk et al. 2002), growth and development rates (Hirst and Kiørboe 2002; Leandro et al. 2006) and mortality rates (e.g. Durbin and Durbin 1981; Hirst and Kiørboe 2002).

However, few attempts have been made to statistically model the response of individual zooplanktonic species as function of multiple environmental variables. This is further complicated by the fact that many parameters co-vary. However, the prediction of the occurrence patterns of zooplanktonic species in estuaries is required in order to understand and forecast any change on zooplanktonic communities due to changes in land-use, habitat loss and climatic instability (Hays et al. 2005). A major concern with a potential ongoing change in climate is that extreme events have a great probability of occurrence (IPCC 2007). In the Mondego estuary, intense precipitation and drought episodes during last years led to significant effects on the structure and functioning of biological communities (e.g. Dolbeth et al. 2007; Marques et al. 2007; Martinho et al. 2007; Cardoso et al. 2008).

Recently, a number of studies addressed the usefulness of statistical models aiming to forecast species distribution, relating ecological variables with environmental factors (Ysebaert et al. 2002; Thrush et al. 2005; Paiva et al. 2008); while these statistical techniques are not new, they have not been applied to zooplanktonic communities. The aim of this study was therefore to model the distribution of zooplanktonic species and to test the robustness of forecast responses with change in environmental variables. Logistic regression was used to model the response of a discrete variable with binominal distribution from a series of continuous and categorical predictor variables. Models were built with data collected in Mondego estuary from 2003 to 2006, encompassing different climatic situations, i.e. drought and flood events (Marques et al. 2007).

\section{Materials and methods}

Study area

The Mondego River estuary, located on the Western coast of Portugal $\left(40^{\circ} 08^{\circ} \mathrm{N}, 8^{\circ} 50^{\circ} \mathrm{W}\right)$, consists of two channels, north and south arm, with contrasting hydrographic characteristics (Fig. 1). The south channel (2-4 m maximum depth, high tide) is almost silted up in the upstream areas, and as a consequence, water circulation is mostly driven by the tidal excursion. The discharge from the Pranto tributary is small and artificially regulated by a sluice according to water needs of the rice crops of the valley (Pardal et al. 2000; Cardoso et al. 2004). The north channel is deeper (maximum 5-10 m, at high tide) and connects directly to the Mondego River. Works of Azeiteiro et al. (1999) and Marques et al. (2006) showed that variations in temperature and salinity in the Mondego estuary provide a large variety of aquatic habitats for populations of marine, brackish and freshwater zooplankton species.

\section{Sample collection and analysis}

The aim of this study was to define the logistic models for some zooplanktonic indicator species and its respective validation. It was not intention to look at any particular microhabitats. Therefore, zooplankton was monthly sampled at five stations comprising both arms (Fig. 1), from January 2003 to December 2005, which represents the major environments found in this estuary, i.e. lower, middle and upper estuary. Salinity, temperature and other

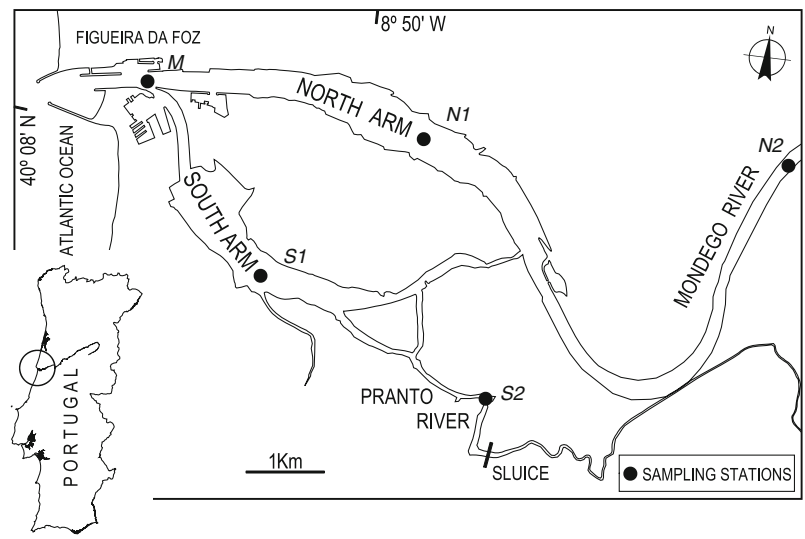

Fig. 1 Map of the Mondego estuary showing the sampling stations: $M$ mouth station, $S 1$ and $S 2$ southern arm stations, N1 and N2 northern arm stations 
environmental parameters regimes found on such zones are sufficiently different to characterize and identify the impact of environmental parameters on the distribution and abundance of zooplanktonic species. Sub-surface tows were carried out horizontally at each station with a bongo net fitted with 335- $\mu \mathrm{m}$ mesh (mouth diameter: $0.5 \mathrm{~m}$ ), equipped with a Hydro-Bios flowmeter. Samples were immediately preserved in $4 \%$ buffered formalin. In the laboratory, zooplankton samples were enumerated (number of individuals per $\mathrm{m}^{3}$ ) and identified to the lowest taxonomic level possible. Simultaneously, at each site, were also recorded salinity, water temperature $\left({ }^{\circ} \mathrm{C}\right)$, dissolved oxygen (DO, $\mathrm{mg} \mathrm{l}^{-1}$ ) and turbidity (Secchi disc depth, m). Water samples were collected for determination in laboratory of chlorophyll $a$ ( $\left.\mathrm{chl} a, \mathrm{mg} \mathrm{m}^{-3}\right)$, total suspended solids (TSS, $\mathrm{mg} \mathrm{l}^{-1}$ ), nitrates $\left(\mathrm{N}, \mathrm{mg} \mathrm{l}^{-1}\right)$, phosphates $\left(\mathrm{P}, \mathrm{mg} \mathrm{l}^{-1}\right)$ and soluble silica $\left(\mathrm{Si}, \mathrm{mg} \mathrm{l}^{-1}\right)$. A detailed description of collection and analysis procedure for Mondego estuary data can be found in Marques et al. (2006). Monthly precipitation values were measured at the Soure $13 \mathrm{~F} / 01 \mathrm{G}$ station and acquired from INAGInstituto da Água (http://www.snirh.inag.pt). Long-term monthly average precipitation was calculated from data collected at the Soure 13F/01G station from 1933 to 2000. Freshwater runoff data from the Mondego river basin were obtained from the INAG station Soure 13F/01G, located near the estuary. Precipitation and freshwater discharge variations in the study period were described in detail by Marques et al. 2007.

\section{Statistical analysis}

Indicator species analysis (ISA $=$ relative abundance $\times$ relative frequency, range from 0 to 100 , Dufrene and Legendre 1997) was used to define and describe which species were typical in each of the sampling stations in the 4 years. These species represent different types of distribution and are indicator species for the zooplanktonic assemblages found in the Mondego estuary, contributing to the total density observed (Azeiteiro et al. 1999; Marques et al. 2007). In addition, multivariate analyses were performed to objectively identify the species' habitat affinities, based on the relationships between species, sampling stations and environmental data. This was achieved by means of a canonical correspondence analysis (CCA), using CANOCO version 4.0 software package (ter Braak and Smilauer 1998).

To model the probability of occurrence of indicator species in relation to the environmental parameters, logistic regression models were used (Hosmer and Lemeshow 2000) using SPSS software, version 12.0 (SPSS, Inc., Chicago, IL, USA). Logistic regression falls within the general framework of the linear model (GLM).
To minimize the variation imposed by seasonality (differences in sampling months) and long-term fluctuation, binary (presence/absence) data were used as the outcome variable.

Univariate analysis was performed for all of the independent variables. The significance of the independent variables was tested using the $\chi^{2}$ test $(P<0.05)$ on the Wald statistic (Hosmer and Lemeshow 2000). Based on such approach, salinity and temperature were selected to generate the response curve for each of the zooplanktonic species. The regression parameters were estimated using the maximum likelihood method. Besides the univariate analysis, all environmental variables were simultaneously used in a stepwise, multiple logistic-regression analysis to derive a model that would predict the presence or absence of zooplanktonic species. The predictive accuracy of the model was assured by direct comparison of model prediction with observed distribution based on data obtained in 2006 (validation). In order to test the effectiveness of the models, additional validation data were obtained in Ria de Aveiro (Canal de Mira)-Portugal, a complex mesotidal shallow coastal lagoon (Fig. 2). Only data on Acartia species were available. This estuarine system acts like a tidally and seasonally poikilohaline estuary (Moreira et al. 1993) and no significant thermal or salinity stratification occurs, except during high peaks of freshwater discharge. Freshwater inputs result mainly from rainfall and runoff

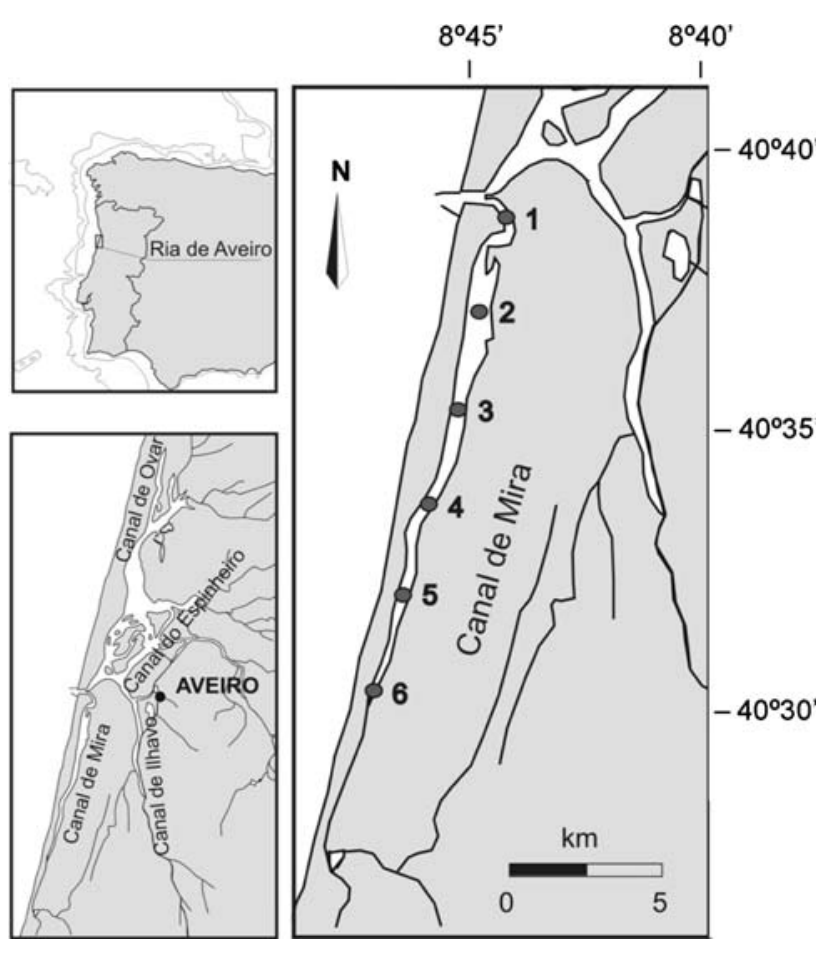

Fig. 2 Location of Ria de Aveiro coastal lagoon (a) and Canal de Mira (b). Circles and numbers indicate the position of the sampling sites $(\mathbf{c})$ 
from the margins. Field sampling campaigns were performed monthly, between August 2000 and June 2002, at six stations distributed along a transect defined from downstream (station 1) to upstream (station 6) (Fig. 2), using the same methodology describe above. During the study period, two contrasting hydrological years were verified: an abnormal wet 2000-2001 and an extremely dry 2001-2002. Those extreme situations revealed to have a significant effect on the longitudinal distribution as well as on the salinity regime (personal communication).

\section{Results}

Abiotic environmental characteristics

The most pronounced spatial gradient in the Mondego estuary was produced by salinity (Table 1 ). Salinity was low in upstream stations, especially in the north arm, decreasing from an average of $26.4( \pm 10.4)$ at the mouth to about $7.3( \pm 8.4)$ in the upper north channel (N2). The water temperature increased a few degrees from the mouth to upper estuary. Secchi disc visibility decreased, while the load of suspended solids increased, usually with increasing distance from the mouth (exception: station N2, Table 1). Dissolved oxygen increased from upper to lower estuary in both arms. Concerning dissolved inorganic nitrogen, the sampling stations were also notably different, with higher values in the upper estuary. The phosphate concentration followed the same distribution pattern. Chlorophyll $a$ concentration values ranged from an average of $3.2( \pm 1.7) \mathrm{mg} \mathrm{m}^{-3}$ in middle south arm (S1) to $8.4( \pm 8.7) \mathrm{mg} \mathrm{m}^{-3}$ in upstream north arm, and lower values were usually observed in downstream estuarine stations.
Indicator species analysis

A total of 102 zooplanktonic taxa were identified in this survey. Table 2 lists the indicator species for each station estimated from ISA. Some similarities among stations were found, which resulted in the selection of 12 species from the zooplanktonic communities of the Mondego estuary that are common members of the different habitats, characterized by their specific hydrological conditions.

Four species were exclusively indicators of the most downstream station (M): Podon leuckarti, Temora longicornis, Muggiaea atlantica and Clausocalanus arcuicornis. In addition, the species Acartia clausi and Evadne nordmanni were also indicators of the lower estuary and associated with the middle south arm. The estuarine species Acartia tonsa and Calanipeda aquaedulcis were consistent indicators of the upper estuary (N2 and S2). For the middle estuary (N1 and S1), the indicator species was Oikopleura dioica; in the north arm, the indicator were Daphnia longispina, Diaptomus castor and Acanthocyclops robustus.

\section{Species-specific habitat}

The environmental preferences of the indicator species selected for the estuary were explored by CCA ordination (Fig. 3). The eigenvalues for Axes 1 (0.519) and 2 (0.211) explained $89.24 \%$ of the cumulative variance in the species data relatively to the total variation explained by the environmental variables. This indicates that the environmental factors considered here accounted for most of the biological variables. The first canonical axis, which explained more than $63 \%$ of the variance is strongly correlated with salinity, and to a lesser extend with freshwater runoff and turbidity (Fig. 3). Total suspended solids and temperature were correlated with the second canonical axis.

Table 1 Mean and standard deviation of salinity (Sal), water temperature $\left(\mathrm{T},{ }^{\circ} \mathrm{C}\right)$, Secchi disc depth (SDD, $\left.\mathrm{m}\right)$, chlorophyll a $\left(\mathrm{chl} a, \mathrm{mg} \mathrm{m}^{-3}\right)$, total suspended solids (TSS, $\left.\mathrm{mg} \mathrm{l}^{-1}\right)$, dissolved oxygen $\left(\mathrm{mg} \mathrm{l}^{-1}\right)$, nitrogen $\left(\mathrm{mg}^{-1}\right)$, phosphorus $(\mathrm{P})$ and soluble silica $\left(\mathrm{mg}^{-1}\right)$

\begin{tabular}{|c|c|c|c|c|c|}
\hline \multirow[t]{2}{*}{ Parameter } & \multirow{2}{*}{$\begin{array}{l}\text { Lower estuary } \\
\text { M }\end{array}$} & \multicolumn{2}{|c|}{ Middle estuary } & \multicolumn{2}{|c|}{ Upper estuary } \\
\hline & & S1 & N1 & $\mathrm{S} 2$ & $\mathrm{~N} 2$ \\
\hline \multicolumn{6}{|l|}{ Abiotic parameters } \\
\hline Sal & $26.4(10.4)$ & $28.6(7.0)$ & $25.5(12.4)$ & $19.1(9.0)$ & $7.3(8.4)$ \\
\hline $\mathrm{T}\left({ }^{\circ} \mathrm{C}\right)$ & $15.3(2.7)$ & $15.7(2.5)$ & $15.5(2.6)$ & $18.2(5.5)$ & $16.9(4.8)$ \\
\hline Secchi disc & $2.2(1.0)$ & $1.6(0.5)$ & $1.7(0.7)$ & $0.5(0.1)$ & $1.1(0.4)$ \\
\hline Chl $a\left(\mathrm{mg} \mathrm{m}^{-3}\right)$ & $3.3(1.9)$ & $3.2(1.7)$ & $3.3(1.8)$ & $10.4(7.2)$ & $8.4(8.7)$ \\
\hline $\operatorname{TSS}\left(\mathrm{mg}^{-1}\right)$ & $22.8(7.9)$ & $24.9(8.9)$ & $23.7(9.6)$ & $32.2(15.3)$ & $14.9(10.1)$ \\
\hline $\mathrm{DO}\left(\mathrm{mg} \mathrm{l}^{-1}\right)$ & $9.3(1.7)$ & $9.0(1.8)$ & $9.2(1.2)$ & $7.4(1.8)$ & $8.4(1.6)$ \\
\hline $\mathrm{N}\left(\mathrm{mg} \mathrm{l}^{-1}\right)$ & $0.2(0.2)$ & $0.2(0.2)$ & $0.3(0.3)$ & $0.3(0.2)$ & $0.8(0.4)$ \\
\hline $\mathrm{P}\left(\mathrm{mg} \mathrm{l}^{-1}\right)$ & $0.02(0.01)$ & $0.02(0.01)$ & $0.02(0.01)$ & $0.05(0.02)$ & $0.05(0.02)$ \\
\hline Soluble silica $\left(\mathrm{mg} \mathrm{l}^{-1}\right)$ & $0.71(0.63)$ & $0.66(0.41)$ & $0.8(0.9)$ & $1.4(0.5)$ & $1.7(0.9)$ \\
\hline
\end{tabular}


Table 2 Zooplankton indicator species $(P<0.05)$ for the five stations of the Mondego estuary. Species are listed by decreasing order of indicator value within each station

\begin{tabular}{lll}
\hline Station & Taxon & Indicator species \\
\hline Mouth (M) & Cladocera & Podon leuckarti \\
& Copepoda & Temora longicornis \\
& Shiphonophora & Muggiaea atlantica \\
& Copepoda & Clausocalanus arcuicornis \\
& Copepoda & Acartia clausi \\
& Cladocera & Evadne nordmanni \\
Middle South arm (S1) & Copepoda & Calanus aquaedulcis \\
& Cladocera & Evadne nordmanni \\
& Appendicularia & Oikopleura dioica \\
& Copepoda & Acartia clausi \\
Copepoda & Acartia tonsa \\
Coper South arm (S2) & Calanus aquaedulcis \\
& Copepoda & Acanthocyclops robustus \\
Middle North arm (N1) & Cladocera & Daphnia longispina \\
& Copepoda & Acanthocyclops robustus \\
& Copepoda & Diaptomus castor \\
Appendicularia & Oikopleura dioica \\
Upper North arm (N2) & Cladocera & Daphnia longispina \\
Copepoda & Diaptomus castor \\
& Copepoda & Acanthocyclops robustus \\
Copepoda & Calanus aquaedulcis \\
Copepoda & Acartia tonsa \\
\hline
\end{tabular}

Based on the species composition, the sampling sites were clustered into different habitats reflecting their hydrological conditions. Downstream stations (M, S1 and N1, open symbols; clustered on the left side of Fig. 3a) were normally associated with salty and relatively transparent waters, except for the winter observations characterized by large freshwater flows. With few exceptions, upstream stations (S2 and N2; solid symbols; clustered on the right side of Fig. 3a) were also separated in the ordination on Axis 1 and were characterized by low salinity values, high nutrient and Chl $a$ concentrations reflecting the direct influence of water runoff, especially the north arm station. Axis 2 also separated the main samples of the middle south arm (S2) which were characterized by higher TSS and warmer temperatures. In Fig. 3b, the zooplanktonic indicator species associated with each habitat is shown.

\section{Univariate response curves}

Logistic regression models were developed for each species, which showed a concordance between 62 and 94\% (Table 3). Figure 4 shows the response curves for each of the 12 zooplanktonic indicator species in relation to salinity and temperature. The obtained response curves were in agreement with the CCA ordination analysis. The probability of occurrence of D. longispina, A. robustus and D. castor, decreased as salinity increased (Fig. 4a). For the last two species, the decrease in the response curve was much smoother, indicating that this species could also occur at higher salinity than the other. For A. tonsa and C. aquaedulcis the model suggested a unimodal curve with an optimal at intermediate salinities and higher probability of occurrence at the middle estuary. The same pattern was observed for $C$. aquaedulcis, which was more sensitive to higher salinity values.

The cladocerans $P$. leuckarti and E. nordmanni, the appendicularian $O$. dioica, the copepods $A$. clausi and the siphonophores $M$. atlantica showed similar response curves, with increasing probabilities of occurrence in the lower estuary. Nevertheless, T. longicornis also showed a high probability of occurrence at higher salinity since this species displayed an almost horizontal curve, indicating a broad tolerance. Clausocalanus arcuicornis showed the highest probability of occurrence at the lower estuary.

Species occurrence also differed as a function of temperature (Fig. 4b). The probability of occurrence of freshwater taxa was highest in colder waters, as those occurring in the upper estuary during high freshwater flow during winter, while the marine species showed a broad tolerance in the range of $15-20^{\circ} \mathrm{C}$, and a steep decline beside this, again in agreement with their observed distribution. The characteristic species of estuarine assemblages differed in their tolerance towards the increase in temperatures. Calanipeda aquaedulcis, for instance, showed a relatively high tolerance, with a still relatively high probability of occurrence in warmer waters. Acartia tonsa showed a bell-shaped curve with an optimum at lower temperature and was also characterized by a lower tolerance to increased temperature.

\section{Multiple logistic regression}

A Spearman correlation matrix was generated to verify for colinearity between variables. Next, possible meaningful interactions between variables were searched. Only those variables (and interactions) that increased their Wald test value and the $G$ test value for the significance of the model were retained in the multivariate model. Since nitrates, phosphates, silica, rainfall and river discharge were highly correlated with salinity, chl $a$ and TSS $(P<0.0001)$ these parameters were not used in the model. The multiple logistic models used to predict the occurrence for each of the 12 zooplankton species contained between 1 and 3 significant parameters (Table 4). Yet, the percentage correctly predicted was high, ranging from 62 to $95 \%$. For the majority of the taxa, salinity was an important explanatory variable, followed by temperature. 
Fig. 3 Biplot diagrams of canonical correspondence analysis (CCA) for a samples and environmental scores and b zooplankton species and environmental scores, for the studied period
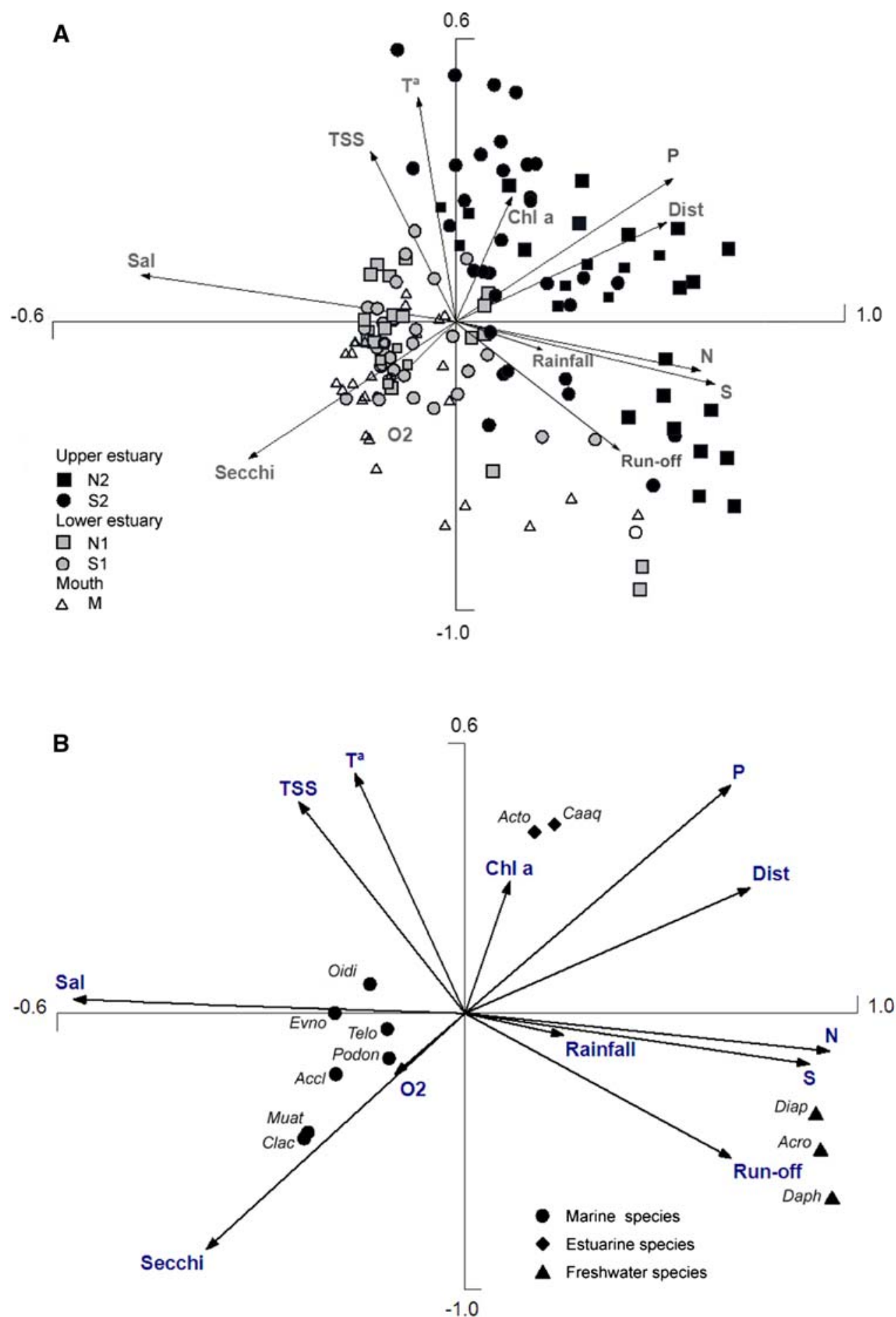

\section{Validation data}

For a few representative example species, the probability of occurrence model appeared to be fairly consistent with the independent observed occurrence in the Mondego estuary (Fig. 5). Daphnia longispina showed a higher occurrence in the north arm which is greatly influenced by freshwater discharge from the Mondego River, especially in the winter, and the probabilities of occurrence coincided with this distribution. Yet, the actual observed occurrence recorded at middle north arm was higher. Acartia tonsa was a relatively common species in the south arm, dominated by tidal circulation. The model concordantly indicated an increased probability of occurrence on such arm. Probability of occurrence of A. clausi was also well predicted by the model, showing an increase in the 
Table 3 Logistic regression models of species occurrence for salinity $(\mathrm{S})$ and water temperature values $(\mathrm{T})$. \% correctly predicted $(\mathrm{CP} \%)$. Logistic regression model: $P(x)=\left(\mathrm{e}^{\text {coef }}\right) /\left(1+\mathrm{e}^{\text {coef }}\right)$

\begin{tabular}{|c|c|c|c|c|c|c|}
\hline \multirow[t]{2}{*}{ Species } & \multicolumn{3}{|c|}{ Salinity } & \multicolumn{3}{|c|}{ Temperature } \\
\hline & $\mathrm{CP} \%$ & $P$ (model) & Exponent coefficient & $\mathrm{CP} \%$ & $P$ (model) & Exponent coefficient \\
\hline \multicolumn{7}{|l|}{ Freshwater species } \\
\hline Daphnia longispina & 93.5 & 0.001 & $0.96-0.40 \mathrm{~S}+0.008 \mathrm{~S}^{2}$ & 89.0 & 0.002 & $2.24-0.29 \mathrm{~T}$ \\
\hline Acanthocyclops robustus & 94.2 & 0.005 & $0.11-0.38 \mathrm{~S}+0.008 \mathrm{~S}^{2}$ & 92.2 & 0.006 & $2.13-0.32 \mathrm{~T}$ \\
\hline Diaptomus castor & 92.9 & 0.001 & $1.12-0.34 \mathrm{~S}+0.006 \mathrm{~S}^{2}$ & 86.4 & 0.047 & $0.34-0.142 \mathrm{~T}$ \\
\hline \multicolumn{7}{|l|}{ Estuarine species } \\
\hline Acartia tonsa & 66.9 & 0.001 & $-1.12+0.21 \mathrm{~S}-0.006 \mathrm{~S}^{2}$ & 68.2 & 0.011 & $6.63-1.03 \mathrm{~T}-0.037 \mathrm{~T}^{2}$ \\
\hline Calanipeda aquaedulcis & 92.9 & 0.038 & $-3.07+0.26 \mathrm{~S}-0.009 \mathrm{~S}^{2}$ & 92.9 & 0.221 & $-11.59+0.96 \mathrm{~T}-0.024 \mathrm{~T}^{2}$ \\
\hline \multicolumn{7}{|l|}{ Marine species } \\
\hline Acartia clausi & 76.0 & $<0.0001$ & $-3.75+0.15 \mathrm{~S}$ & 79.1 & $<0.0001$ & $-17.14+2.08 \mathrm{~T}-0.060 \mathrm{~T}^{2}$ \\
\hline Temora longicornis & 62.3 & $<0.0001$ & $-1.94+0.06 \mathrm{~S}$ & 63 & 0.002 & $-10.45+1.19 \mathrm{~T}-0.03 \mathrm{~T}^{2}$ \\
\hline Clausocalanus arcuicornis & 90.9 & 0.015 & $-7.05+0.16 \mathrm{~S}$ & 90.9 & 0.047 & $-24.25+2.77 \mathrm{~T}-0.085 \mathrm{~T}^{2}$ \\
\hline Muggiaea atlantica & 83.1 & $<0.0001$ & $-5.64+0.14 S$ & 83.1 & 0.002 & $-28.27+3.053 \mathrm{~T}-0.084 \mathrm{~T}^{2}$ \\
\hline Podon leuckarti & 85.7 & 0.016 & $-3.65+0.07 \mathrm{~S}$ & 85.7 & 0.006 & $-30.53+3.021 \mathrm{~T}-0.076 \mathrm{~T}^{2}$ \\
\hline Evadne nordmanni & 84.4 & 0.001 & $-6.325+0.16 \mathrm{~S}$ & 84.4 & 0.006 & $-11.59+0.96 \mathrm{~T}-0.024 \mathrm{~T}^{2}$ \\
\hline Oikopleura dioica & 79.2 & $<0.0001$ & $-6.03+0.17 \mathrm{~S}$ & 77.9 & $<0.0001$ & $-27.67+3.020 \mathrm{~T}-0.083 \mathrm{~T}^{2}$ \\
\hline
\end{tabular}

polyhaline zone of the estuary. For T. longicornis the actual occurrence observed was lower than the model's prediction. However, a low decrease observed in the north arm was consistent with the predictions of the model. Finally, for E. nordmanni was observed a polyhaline distribution which coincided with the probability of occurrence model. Results for the probability of occurrence of the zooplanktonic species appear to be consistent with the presence and absence for the Canal de Mira-Ria de Aveiro, as shown in Fig. 5 for the Acartia species. Acartia tonsa was observed along the complete salinity gradient, mainly at the middle estuary, and the highest probabilities of occurrence coincided with this distribution. Although the model prediction of occurrence was not as sensitive, it predicted, in concordance, a much broader distribution for this species, while A. clausi had mainly a polyhaline distribution. The model indicated in agreement a higher probability of occurrence in the lower estuary.

\section{Discussion and Conclusions}

Compared with the terrestrial environment, the pelagic realm has few physical barriers obstructing the mixing of planktonic species. Nevertheless, there are some hydrographic barriers between different water masses which have distinct physico-chemical conditions and ecological properties (Beaugrand et al. 2002). In the case of coastal waters, effective maintenance of the native biodiversity in face of increasing human impacts and climatic variability requires accurate measurements of key trends and responses to disturbance and effective management actions.

In this study, we aimed to developed models to predict the spatial distribution of zooplanktonic species with change of environmental conditions. The use of zooplanktonic species as indicators of specific water-masses has long been stressed at a global (Russell 1973; Beaugrand 2004) and local scale (Bonnet and Frid 2004; Whitman et al. 2004). As an alternative to conducting exhaustive species inventories, scientists and management practitioners hope that the species richness can be predicted more cheaply and quickly through the use of "indicator" species (Pearson 1994). This concept is defined here as species with occurrence patterns that are correlated with a specific zone of the estuary. Therefore, from the present database we selected 12 zooplanktonic indicator species, characterized by specific ecological requirements, of 3 different zones of the Mondego estuary. Logistic models based on the occurrence of those indicator species were then successfully constructed and the distribution (presence/absence) of different zooplanktonic species based on environmental variables at a local scale showed to be well predicted.

The comparisons of the models revealed wide variations in species response to change in environmental conditions. In this study, non-resident species such as polyhaline and freshwater species showed lower tolerance to salinity, being observed at the lower and upper estuary, respectively. On the other hand, ubiquitous species such as A. tonsa and $C$. aquaedulcis were observed along the salinity gradient, mainly at the mesohaline zone of the 
Fig. 4 Probability of occurrence $(P)$ of the zooplanktonic species of Mondego estuary fitted with logistic regression in relation to a salinity and $\mathbf{b}$ temperature. Curves were only drawn for the range of salinity and temperature values observed for each species-specific habitat of the estuary

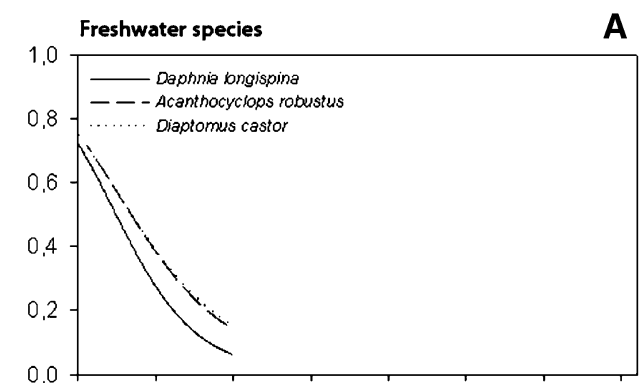

A

B
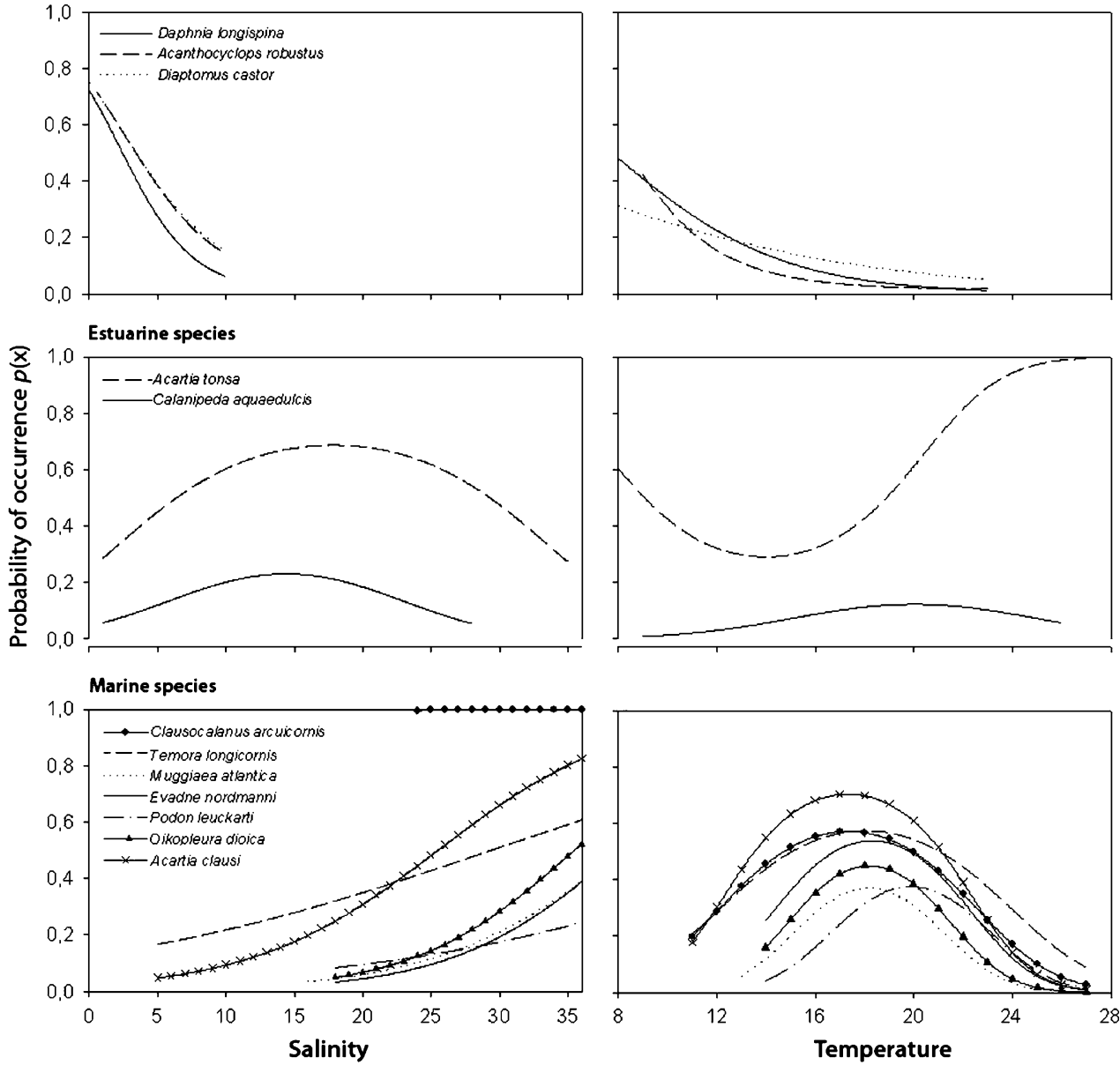

Table 4 Multiple logistic regression model analysis showing the significant variables for each species $(x), \%$ correctly predicted $(\mathrm{CP} \%)$. Other abbreviations as in Table 1

\begin{tabular}{|c|c|c|c|c|c|c|c|}
\hline Species & Sal & $\mathrm{T}$ & Turb & Chl $a$ & TSS & DO & $\mathrm{CP} \%$ \\
\hline \multicolumn{8}{|l|}{ Freshwater species } \\
\hline Daphnia longispina & $x$ & & & & & & 94.8 \\
\hline Acanthocyclops robustus & $x$ & & & & & & 92.2 \\
\hline Diaptomus castor & $x$ & & & & & & 92.9 \\
\hline \multicolumn{8}{|l|}{ Estuarine species } \\
\hline Acartia tonsa & & $\times$ & $x$ & & & $\times$ & 70.8 \\
\hline Calanipeda aquaedulcis & & & $x$ & & & & 92.9 \\
\hline \multicolumn{8}{|l|}{ Marine species } \\
\hline Acartia clausi & $\times$ & $x$ & & $\times$ & & & 79.2 \\
\hline Temora longicornis & $x$ & & & & & & 62.3 \\
\hline Clausocalanus arcuicornis & $x$ & & & & & & 90.9 \\
\hline Muggiaea atlantica & $x$ & & & & & & 83.1 \\
\hline Podon leuckarti & $x$ & $\times$ & & & & & 83.8 \\
\hline Evadne nordmanni & $x$ & $x$ & & & & & 83.8 \\
\hline Oikopleura dioca & $x$ & & & & $\times$ & & 78.6 \\
\hline
\end{tabular}

estuary, exhibiting a broad tolerance. According to Day et al. (1989) most estuarine zooplanktonic organisms have evolved to broad physiological tolerance in order to ensure their survival into unstable environmental conditions such as ones that characterize estuarine ecosystems.

Additionally, the strong correlation of zooplankton distribution with water temperature is not surprising (Fulton 1984; Fernandez de Puelles et al. 2004; Marques et al. 2006). Although most estuarine species are eurythermic (e.g. Lance 1963; Tackx et al. 2004), many studies have shown that individual zooplanktonic species have an optimum temperature range and may not survive outside such temperatures (Leandro et al. 2006). Our findings are consistent with other studies that also analysed the temporal and spatial patterns of the zooplankton species composition and abundance. Such studies concluded that the main environmental gradient was formed by water temperature and salinity and a similar pattern of species distribution was observed (Escaravage and Soetaert 1995; Mouny and Dauvin 2002; Tackx et al. 2004). 
Fig. 5 Observed occurrence (bars) of some zooplanktonic species studied and the probability of occurrence (solid line) determined by multiple logistic regression (left column Mondego Estuary, right column Ria de Aveiro)
Freshwater species

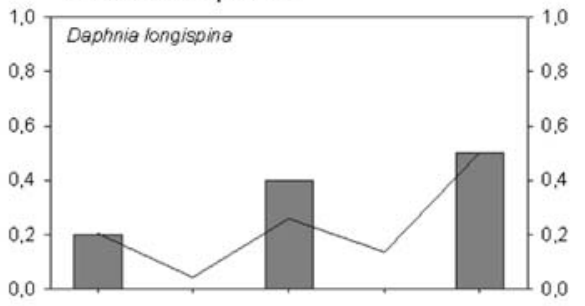

Estuarine species
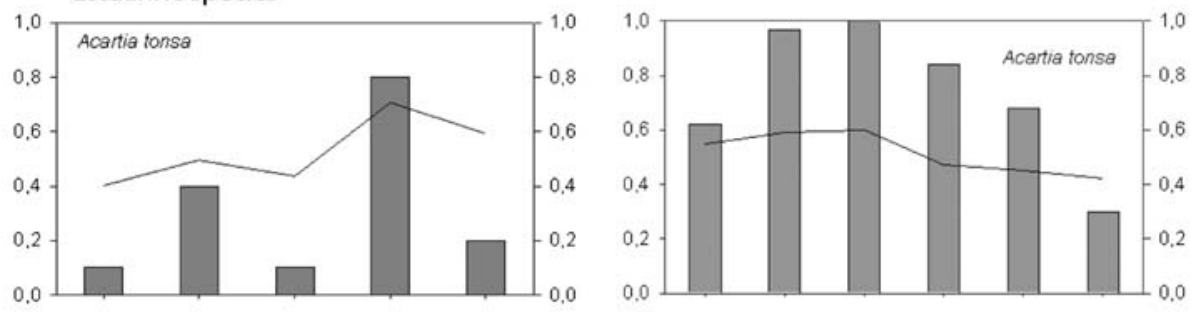

Marine species
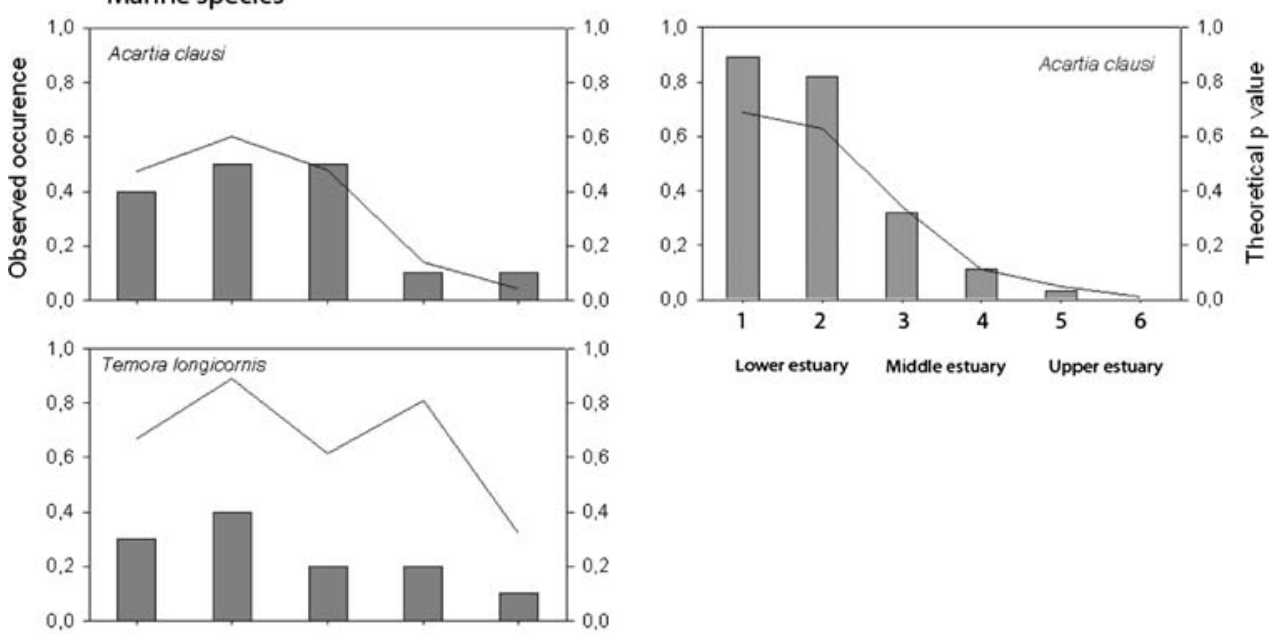

Lower estuary Middle estuary Upper estuary

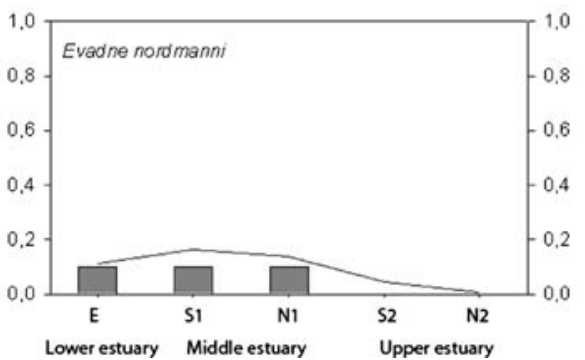

Based on our results, the logistic regression proves to be a useful approach for predicting the occurrence of species under varying environmental conditions along an estuarine gradient. Therefore, this model can be considered of reasonable application given its ability to predict the occurrence of individual species associated with habitat. In our model approach we used single environmental parameters as predictors of zooplanktonic species distribution. Although it is well known that the factors that cause species distribution interact in complex ways, it is not surprising that simple correlations with a single environmental change are not always observed. The pattern recorded in this study may also reflect the use of a zooplankton net with $335-\mu \mathrm{m}$ mesh size. This coarse mesh net may have undersampling small zooplankton specimens, such as copepodites of Acartia and Temora which in turn may lead to a limited view of the ecology of planktonic systems. A more suitable spatial and temporal survey of zooplankton populations is being carried out in Mondego estuary, which we hope will confirm its biological implication in this system. Given this, the comparison with other data should be considered with some caution. 
Pronounced environmental stochasticity often diminishes the predictive ability of correlative models. However, the effects of precipitation extremes were detectable in the comparison between predicted and observed values of species occurrence in our study. For example, the models correctly predicted an increase in occurrence of freshwater species in the north arm in 2006, which was coincident with a high freshwater flow in that year. Biotic factors such as predation, competition, as well as mortality and survival may also influence the distribution and diversity of pelagic organisms (Gaudy et al. 2000; Hansson et al. 2005; Badosa et al. 2007) by decreasing its potential range. On the other hand, advective processes which control the influx of zooplankton from source areas and the continuous loss to downstream areas (Marques et al. 2007) increases its potential range.

Wherever it may not provide enough information to understand the nature of a given observed pattern, statistical models could be useful to forecast species distribution within the scope of ecological and environmental management, since such models indicate the long-term consequences of habitat changes. The approach detailed here could also have an important utility for assessing the environmental conditions influencing the distribution of zooplankton across broad spatial scales such as ocean basins. Such data sets are provided by large scale sampling programs such as the Continuous Plankton Recorder Survey (Warner and Hays 1994) and have been used to describe species assemblages (Beaugrand et al. 2002). Over such large scale, additional environmental factors, such as water depth, may play roles as well as temperature and salinity (Hays 1996). For example, water depth dictates the ability of large vertical migrating species of zooplankton to occupy particular areas.

One of the most important contributions of the present study is that it may enhance our ability to conduct localscale ecological assessment and to make effective conservation decisions. Effective maintenance of biodiversity in the face of increasing human impacts and climatic variability requires accurate measurements of key trends and responses to disturbance and alternative management actions. Zooplankton plays several important roles in estuarine ecosystems, since they serve as an important link between phytoplankton primary production and many important estuarine carnivorous, including many crustaceans and fishes (Kiorboe and Nielsen 1994; Hays et al. 2005). A large number of benthic and nektonic organisms spend part of their life cycle in the plankton (merozooplankton), and as such the plankton stages influence the distribution and abundance of the adult populations. In addition, responses by individual species to environmental changes may disrupt their interactions with others at the same or other trophic levels. As an example, a modification in secondary production will affect the availability of planktonic food for fish larvae, which determines the recruitment success and consequently the size of fish population (Cushing 1990). In addition, jellyfish may be very important consumers in some coastal ecosystems, including estuaries (e.g. Houghton et al. 2006; Perez-Ruzafa et al. 2002), and zooplankton species composition may influence whether fish or jellyfish dominate a particular system. Therefore, the ability to forecast changes in the spatial distribution of zooplanktonic species also yields important insights into the threat that loss of habitat diversity may pose to biological diversity and ecosystem health.

Acknowledgments The present work was supported by I.I. I. (Instituto de Investigação Interdisciplinar of the University of Coimbra) through a Ph.D grant awarded to S. C. Marques (III/AMB/28/2005). A special thanks to all colleagues who helped during field work.

\section{References}

Anger K (2003) Salinity as a key parameter in the larval biology of decapod crustaceans. Invertebr Reprod Dev 43:29-45

Azeiteiro UMM, Marques JC, Ré P (1999) Zooplankton annual cycle in the Mondego river estuary (Portugal). Arq Mus Bocage 3:239-263

Badosa A, Boix D, Brucet S, López-Flores R, Gascón S, Quintana XD (2007) Zooplankton taxonomic and size diversity in Mediterranean coastal lagoons (NE Iberian Peninsula): influence of hydrology, nutrient composition, food resource availability and predation. Estuar Coast Shelf Sci 71:335-346. doi:10.1016/ j.ecss.2006.08.005

Beaugrand G (2004) The North Sea regime shift: evidence, causes, mechanisms and consequences. Prog Oceanogr 60:245-262. doi: 10.1016/j.pocean.2004.02.018

Beaugrand G, Reid PC, Ibanez F, Lindley JA, Edwards M (2002) Reorganization of North Atlantic marine copepod biodiversity and climate. Science 296:1692-1694. doi:10.1126/science.1071329

Berasategui AD, Menu-Marque S, Gómez-Erache M, Ramírez FC, Mianzan HW, Acha EM (2006) Copepod assemblages in a highly complex hydrographic region. Estuar Coast Shelf Sci 66:483-492. doi:10.1016/j.ecss.2005.09.014

Blanco-Bercial L, Alvarez-Marques F, Cabal JA (2006) Changes in the mesozooplankton community associated with the hydrography off the northwestern Iberian Peninsula. ICES J Mar Sci 63:799-810. doi:10.1016/j.icesjms.2006.03.007

Bonnet D, Frid CLJ (2004) Seven copepod species considered as indicators of water-mass influence and changes: results from a Northumberland coastal station. ICES J Mar Sci 61:485-491. doi:10.1016/j.icesjms.2004.03.005

Cardoso PGM, Pardal MA, Lillebø AI, Ferreira SM, Raffaelli D, Marques JC (2004) Dynamics change in seagrass assemblages under eutrophication and implication for recovery. J Exp Mar Biol Ecol 302:233-248. doi:10.1016/j.jembe.2003.10.014

Cardoso PG, Raffaelli D, Lillebø AI, Verdelhos T, Pardal MA (2008) The impact of extreme flooding events and anthropogenic stressors on the macrobenthic communities' dynamics. Estuar Coast Shelf Sci 76:553-565. doi:10.1016/j.ecss.2007.07.026

Cushing DH (1990) Plankton production and year-class strength in fish populations: an update of the match-mismatch hypothesis. Adv Mar Biol 26:249-293. doi:10.1016/S0065-2881(08)60202-3

Day J, Hall CAS, Kemp WM, Yanez-Arancibia A (1989) Estuarine ecology. Wiley, New York

Dolbeth M, Cardoso PG, Ferreira SM, Verdelhos T, Raffaelli D, Pardal MA (2007) Anthropogenic and natural disturbance effects on a 
macrobenthic estuarine community over a 10-year period. Mar Pollut Bull 54:576-585. doi:10.1016/j.marpolbul.2006.12.005

Dufrene M, Legendre P (1997) Species assemblages and indicator species: the need for a flexible asymmetrical approach. Ecol Monogr 67(3):345-366

Durbin AG, Durbin EG (1981) Standing stock and estimated production rates of phytoplankton and zooplankton in Narragansett Bay. R I Estuaries 4:24-41. doi:10.2307/1351540

Escaravage V, Soetaert K (1995) Secondary production of the brackish copepod communities and their contribution to the carbon fluxes in the Westerschelde estuary (The Netherlands). Hydrobiologia 311:103-114. doi:10.1007/BF00008574

Fernandez de Puelles ML, Valencia J, Jansa J, Morillas A (2004) Hydrographical characteristics and zooplankton distribution in the Mallorca channel (Western Mediterranean): spring 2001. ICES J Mar Sci 61:654-666. doi:10.1016/j.icesjms.2004.03.031

Fulton RS (1984) Distribution and community structure of estuarine copepods. Estuaries 7:38-50. doi:10.2307/1351955

Gaudy R, Cervetto G, Pagano M (2000) Comparison of the metabolism of Acartia clausi and A. tonsa: influence of temperature and salinity. J Exp Mar Biol Ecol 247:51-65. doi: 10.1016/S0022-0981(00)00139-8

Halsband-Lenk C, Hirche HJ, Carlotti F (2002) Temperature impact on reproduction and development of congener copepod populations. J Exp Mar Biol Ecol 271:121-153. doi:10.1016/S00220981(02)00025-4

Hansson LJ, Moeslund O, Kiørboe T, Riisgård HU (2005) Clearance rates of jellyfish and their potential predation impact on zooplankton and fish larvae in a neritic ecosystem (Limfjorden, Denmark). Mar Ecol Prog Ser 304:117-131. doi:10.3354/meps304117

Hays GC (1996) Large scale patterns of diel vertical migration in the North Atlantic region. Deep Sea Res Part I Oceanogr Res Pap 43:1601-1615. doi:10.1016/S0967-0637(96)00078-7

Hays GC, Richardson AJ, Robinson C (2005) Climate change and marine plankton. Trends Ecol Evol 20:337-344. doi:10.1016/ j.tree.2005.03.004

Hirst AG, Kiørboe T (2002) Mortality of marine planktonic copepods: global rates and patterns. Mar Ecol Prog Ser 230:195-209. doi: $10.3354 /$ meps 230195

Hosmer D, Lemeshow S (2000) Applied logistic regression. Wiley, New York

Houghton JD, Doyle TK, Wilson MW, Davenport J, Hays GC (2006) Jellyfish aggregations and leatherback turtle foraging patterns in a temperate coastal environment. Ecology 87:1967-1972. doi: 10.1890/0012-9658(2006)87[1967:JAALTF]2.0.CO;2

Hughes L (2000) Biological consequences of global warming: is the signal already apparent? Trends Ecol Evol 15:56-61. doi: 10.1016/S0169-5347(99)01764-4

IPCC (2007) Climate change 2007: the Physical Science Basis. Summary for Policymakers, Paris, February 2007

Kiorboe T, Nielsen TG (1994) Regulation of zooplankton biomass and production in a temperate, coastal ecosystem. 1. Copepods. Limnol Oceanogr 39:493-507

Lance J (1963) The salinity tolerance of some estuarine plankton copepods. Limnol Oceanogr 8:440-449

Leandro SM, Queiroga H, Rodriguez L, Tiselius P (2006) Temperature dependent development and somatic growth in two allopatric populations of Acartia clausi (copepoda: calanoida). Mar Ecol Prog Ser 322:189-197. doi:10.3354/meps322189

Marques SC, Azeiteiro UM, Marques JC, Neto JM, Pardal MA (2006) Zooplankton and ichthyoplankton communities in a temperate estuary: spatial and temporal patterns. J Plankton Res 28:297312. doi:10.1093/plankt/fbi126

Marques SC, Azeiteiro UM, Martinho F, Pardal MA (2007) Climate variability and planktonic communities: the effect of an extreme event (severe drought) in a southern European estuary. Estuar Coast Shelf Sci 73:725-734. doi:10.1016/j.ecss. 2007.03.010

Martinho F, Leitão R, Viegas I, Dolbeth M, Neto JM, Cabral HN et al (2007) The influence of an extreme drought event in the fish community of a southern Europe temperate estuary. Estuar Coast Shelf Sci 75:537-546. doi:10.1016/j.ecss.2007.05.040

McLusky DS, Elliott M (2004) The estuarine ecosystem. Oxford University Press, Oxford

Moreira MH, Queiroga H, Machado MM, Cunha MR (1993) Environmental gradients in a southern estuarine ecosystem: Ria de Aveiro, Portugal. Implication for soft bottom macrofauna colonization. Neth J Aquat Ecol 27:465-482. doi:10.1007/ BF02334807

Mouny P, Dauvin J-C (2002) Environmental control of mesozooplankton community structure in Seine estuary (English Channel). Oceanol Acta 25:13-22. doi:10.1016/S0399-1784(01)01177-X

Paiva V, Ramos JA, Martins J, Almeida A, Carvalho A (2008) Foraging habitat selection by Little Terns Sternula albifrons in an estuarine lagoon system of southern Portugal. Ibis 150:18-35

Pardal MA, Marques JC, Metelo I, Lillebø AI, Flindt MR (2000) Impact of eutrophication on the life cycle, population dynamics and production of Ampithoe valida (Amphipoda) along an estuarine spatial gradient (Mondego estuary, Portugal). Mar Ecol Prog Ser 196:207-219. doi:10.3354/meps 196207

Pearson DL (1994) Selecting indicator taxa for the quantitative assessment of biodiversity. Philos Trans Roy Soc Lond B 345:75-79

Perez-Ruzafa A, Gilabert J, Gutierrez JM, Fernandez AI, Marcos C, Sabah S (2002) Evidence of a planktonic food web response to changes in nutrient input dynamics in the Mar Menor coastal lagoon, Spain. Hydrobiologia 475/476:359-369. doi:10.1023/ A: 1020343510060

Queiroga H, Blanton J (2004) Interactions between behaviour and physical forcing in the control of horizontal transport of decapod crustaceans larvae. Adv Mar Biol 47:107-204. doi:10.1016/ S0065-2881(04)47002-3

Roddie BD, Leakey RJG, Berry AJ (1984) Salinity-temperature tolerance and osmoregulation in Eurytemora affinis (Poppe) (Copepoda: Calanoida) in relation to its distribution in the zooplankton of the upper reaches of the Forth estuary. J Exp Mar Biol Ecol 79:191-211. doi:10.1016/0022-0981(84)90219-3

Russell FS (1973) Hydrographical and biological conditions in the North Sea as indicated by plankton organisms. J Cons Int Explor Mer 14:171-192

Tackx MLM, Nathalie DP, Riet VM, Azemar F, Abdelhacq H, Stefan VD et al (2004) Zooplankton in the Schelde estuary, Belgium and The Netherlands. Spatial and temporal pattern. J Plankton Res 26:133-141. doi:10.1093/plankt/fbh016

Ter Braak CJF, Smilauer P (1998) CANOCO Reference Manual and User's Guide to Canoco for Windows: Software for Canonical Community Ordination (version 4). Microcomputer Power, Ithaca, New York

Thrush SF, Hewitt JE, Herman PMJ, Ysebaert T (2005) Multi-scale analysis of species-environment Relationships. Mar Ecol Prog Ser 302:13-26. doi:10.3354/meps302013

Warner AJ, Hays GC (1994) Sampling by the continuous plankton recorder survey. Prog Oceanogr 34:237-256. doi:10.1016/00796611(94)90011-6

Whitman RL, Meredith BN, Goodrich ML, Murphy PC, Bruce MD (2004) Characterization of Lake Michigan coastal lakes using zooplankton assemblages. Ecol Indic 4:277-286. doi:10.1016/ j.ecolind.2004.08.001

Ysebaert T, Meire P, Herman P, Verbeek H (2002) Macrobenthic species response surfaces along estuarine gradients: prediction by logistic regression. Mar Ecol Prog Ser 225:79-95. doi: $10.3354 /$ meps 225079 